\title{
A CUT VIEW CONCERNING THE ECONOMIC TRANSFORMATION GENERATED BY THE WEALTH TAX: SEIZURE FOR BAHTIYAR HAN
}

\author{
Başak Ergüder ${ }^{*}$
}

\begin{abstract}
The official goal of Wealth Tax Law implemented to point the excessive profits gained via black market and monopoly as target in eliminating the shortages caused by the money supply shortages and high inflation rates in Turkey during World War II. But the hidden goal of this this law was to realize an economical transformation. The classification of the taxpayers as $G$ (Non-muslims), $M$ (Muslims), $D$ (Proselyte) and E (Foreigners), the inclination towards real estates owners and merchants in tax assessment, tax collection made mostly in Istanbul caused a problematic table in terms of taxation principles. 87 per cent of all taxpayers in Turkey was non-muslims and 54 per cent was in Istanbul. 68 per cent of the taxes accrued in Turkey was accrued in Istanbul and 70 per cent of the taxes collected in the country was paid in Istanbul. It can be clearly seen in this table that this tax could not realise the principle of universality and equality and that the outputs of Wealth Tax was to realize the economical transformation. In this study, the outputs of the economical transformation generated by the Wealth Tax Law will be analyzed in terms of Turkification of the economy. Although the target of reducing the money supply and decreasing the inflation rates were not accomplished via Wealth Tax Law, the economic transformation, which was the hidden goal of the law, was realized. In this study it will be focused in the role of SEE's and public organizations in the sales and seizures made due to Wealth Tax. The seizure of Bahtiyar Han's possessions by the Soil Products Office will be analyzed. This case deserves to be discussed and analyzed in terms of showing the mentality of the economical transformation and of the role of the public organizations in this period.
\end{abstract} Han.

Keywords: Wealth Tax, Economic Transformation, Turkification of the Economy, Bahtiyar

Jel Codes: H20,K34,N40

\section{INTRODUCTION}

The discussions concerning the content and implementations of the 4305 numbered Law About Wealth Tax which was introduced on 11th of November 1942, are stil continuing. It is discussed by the supporters of Wealth Tax Law that money emission should be contradicted for high inflation rates by taking the conditions of the World War II into consideration and it is pointed out that the target income was not achieved in practice. It is alleged that the assessment tax is low compared to the collection in terms of rates and thus the law could not achieve its target (Kayra,2011: 77-83). It is a fact that the targeted tax income rate was not achieved in Wealth Tax implementation. Although the tax collection rate was 70 per cent in İstanbul, the city where the highest assessment rate was achieved in Turkey, when we compare the assessment tax rate and collection rate, we can tell that the absence of right of objection against the law and sending those who could not pay the tax debt to the labour

\footnotetext{
* Assist. Prof. Dr., Istanbul University, Turkey, E-mail: berguder@ istanbul.edu.tr
} 
camps brought the sale of real properties and the seizures into question to collect the taxes. This situation started a process in which the compatible outputs for Turkification of the economy, the real goal of Wealth Tax, were arised and an appropriate investment atmosphere were created for the Turkish entrepreneurs to hold the dominance of the market.

The value of the entities seized in accordance with the Wealth Tax is important in that it shows that the subjective criterias played their roles in determining the tax rates. Especially, the actions such as taking such real properties as apartments and office buildings into consideration in determining the tax payments of the taxpayers and such as investing consumption patterns as life quality indicator was not only against the definiteness principle of the tax but also caused the punishment of the wealthy sections by making them disposessed.

In this study, the subjects to be focused on are the fact that the taxpayers possessions played an important role in both the determination of tax amount and the collection of the tax and the reasons and consequences of the transfer of the capital from the non-muslims to Turks by the state bureaucracy in the taxation process. Thus, it will be useful to handle the historical development of such concepts as the state, state power and bureaucracy from Otoman Empire till Turkish Republic.

\section{TURKIFICATION OF THE ECONOMY}

The concept of state power is stated as the special capacity of the state which is the total of complex social relations influencing the balance generating and making the capital accumulation between the social powers in a given period in history (Jessop, 2008:28). Thus, the state is the institutional field where the struggle between many different political powers including the special capacities of the state, those state governors attempting to control the state power takes place (Jessop,2008: 31). State is the balance of the complex social relations in a given period, and thus the state power has such a complex structure and a social relations body not to be reduced to class power. A similar concept to the concept of state power is the Bonapartist Balance Concept defining the balance between the social groups, which is directed by the state (Mann,2003:60). The functions of the state such as protecting the property relations, providing the defence and infrastructure services and distribution of sources change depending on the conditions of the social groups contacted by the state, such as being wider or narrower than the present social classes. The Bonapartist Balance provide the state with a specific freedom of action and the state power is born in this space (Mann,2003: 59).

State power controls the actions, spaces - the fluency and site selection - of the capital and a bureaucracy process is experienced in the arrangement period with the arranging function. (Lefebvre,2003: 95). The capital was moved from İstanbul to Ankara, its new place to be established across a bureaucratized place in a period when the Wealth Tax was in implementation. It is seen when the studies made about the state are analyzed that the patrimonial/powerful state approach is a well accepted expositive approach (Keyder1982; Buğra,1996; Insel,2001). It is thought that the bureaucracy has a patrimonial/powerful state tradition as the production was for the provision of the needs of the state in Otoman Empire and bureaucracy is a group associated with the benefits of the state (Dinler, 2003: 20).

Tax policies are distinguished as the most important parameter representing the state power. The borrowing mechanism established with the tax policy arranging the needs between the rural and urban areas and the financial currents played an important role in the formation of bourgeoisie. It is observed that the politicised capital accummulation which lead the capital accumulation processes and which was genereated by the patrimonial/powerful 
state tradition in Ottoman Empire is still continuing. The patrimonial/powerful state tradition continuing in 1920's caused the state power to be held in certain people (Dinler, 2003:34). Many examples concerning the affiliation of the state and bureaucracy in the monopoly profits gained by the bourgeoisie developed by the state and by the public institutions can be seen in 1920's. The most important example for this situation is the fact that the staff establishing Isbank also established the ruling party.

The Etatism (Statism) coming into question after 1929 Economic Crisis is in accordance with the state's interventions into the social life and powerful/despot state idea for bringing prosperity. The special aim of the etatist hegemony project of the state was making development possible in 1930's. The state wielded power over the society in building the economic development (Yalman, 2002:10).

The primary goal continuing to be headed for from 1920's to 1930's and leading the economy-policies in 1930's was the establishment of the state control over the financial and economic institutions (Ahmad, 2008: 206). The investments necessary for economic development responded to the source problem of the businessmen being in uncertainty and insecurity and having not enough capital accumulation with the despot state answer.

The traces of this approach can be seen in the national banks established and the fiveyear development plans made in 1930's and the state intervention for generating the private sector and Turkish bourgeoisie become prominent as the primary economy-policy tool. Thus, we can say that the Kadro Journal leading the economic life and the politicians of the period played an important role in a series of legal arrangements and the formation of the institutions to undertake the mission to strengthen the Turkish bourgeoisie in the second half of 1930's (Ahmad, 2008: 216-17). The etatist hegemony project had the features of the organic and advanced capitalist society it attempted to build. A classless and coherent mass discourse could only be possible via an homogenising arrangement uniting the state power and capitalists if a modern, cosmopolitic and class society exist. The process of Turkification of the economy, which is one of the socialization practices experienced by the classes and the politic subjects who are the politic representatives of these classes within the framework of the structure forming the state, should be focused on in analyzing the Wealth Tax Implementation in the economic-politic developments in Turkey throughout World War II with reference to Jessop's state analysis (Jessop,2008: 31). The process of Turkification of the economy was experienced in this period with a mentality and taxation approach devoted to remove the obstacles before the national bourgeoisie being generated by the state.

The stricter legal precautions taken and the National Security Law, The Law of Establishing Import and Export Unions and Wealth Tax Law prepared were legal arrangements speeding up the Turkicization of the economy in the shortages caused by World War II. The prices in the market were being regulated by the state and the newly-borne bourgeoisie gained place in the market through these three laws. The state had the chance to act relatively autonomously against the non-muslim bourgeoisie:

"Historically, the Wealth Tax is one of the rare examples showing that the state with changing priorities relatively gained autonomy from the structural dependence on the capital and applied increases on the tax burdens of the wealthy communities (Karabacak, 2005: 116)."

The etatist hegemony project restructured the state's tradition with the new taxation policy. As Şükrü Saraçoğlu stated in his speech in the Assembly during the negotiations on the Wealth Tax Law, the target in the economy was "to give Turkish market to Turks" (Bali, 2005a: 478). The conditions having aroused from the economy of scarcity during the Second 
World War and the discourse of engrossing about the importers created a suitable environment for the transformation in the economy to be formed by all laws issued in the preparation process of the Tax. The Wealth Tax, which, in the opinion of Çalıs (1997: 107) was to be accepted as a part of racist policies in economy in the years of the Second World War, did not avoid from seizing the incomes of wealthy non-Muslim people in order to achieve the goal of "protecting Turkish Market". The Wealth Tax application, which was deemed as an obligation to eliminate the economic/financial problems under the conditions of that period, had anti-Semitic characteristics with practices such as jailing the non-Muslim people and sending them to work camps. These practices in which properties of the taxpayers were seized and they had no right to object, violates the civil rights. It is seen that there is a chronic parallelism between the anti-Semitism that was on the scene in Europe during 1930s and 1940s and the racist policies that aroused in Turkey's public sphere. Thrace pogroms, Turkish speaking campaign and the Wealth Tax are seen as the reflections of the rising antiSemitism on the public sphere (Aktürk, 2007: 41).

\section{WEALTH TAX IN TERMS OF TAXATION PRINCIPLES}

It is seen that the government played an active role in the capital transfer through the Wealth Tax Law, which led to an extraordinary situation due to the violation of taxation principles in terms of public finance. When Wealth Tax is examined in respect of taxation principles, it is easily seen that this tax does not comply with the principles of equality, generality, certainty and economy. That different scales were applied for the taxpayers gaining the same income and the tax to be paid was far beyond their financial power is contrary to the principal of equality in taxation. Four different scales were applied for the Non-Muslim (N), Muslim (M), Foreign (F) and Apostate (A). There were four classes for Muslim taxpayers, which were exceptional class, those with revenue, those with return and the medium class and six classes for Non-Muslim taxpayers, including service providers and peddlers. Joint-stock Companies, Large Farmers and Real Estate Owners were the taxpayers apart from the groups with scales (Ökte, 1954: 65-66). Tax collected from the group N was five times more than the tax collected from the group $\mathrm{M}$, the highest tax amount was imposed on the contractors and brokers in the group $G$ and also tax amounts collected from the companies held by N-M partners were such that would lead to the bankruptcy of Non-Muslim shareholders (Ökte, 1954: 67) and all these totally eliminated the equality.

The principle of equality was also damaged by the fact that one could not file suit against the decision of the commission related to tax pursuant to the Article 11 of the Wealth Tax Law and suits could only be filed if there was a repeating tax. It was another violation of the principle of equality in taxation that, in case of repeating tax, the higher one was applied and the other one was canceled and this cancellation could only be performed by the biggest officer of the location where the commissions were in charge (Akar, 2009: 178).

The principle of certainty was violated by relying on the consumption patterns, lifestyles and personal characteristics like philanthropy of the taxpayer in the determination of the tax amount based on the real estate and writing the tax amounts on the tax tables with lead pencils (Akar, 2009: 177). Determination of tax amounts by the commissions was totally based on the consumption patterns (good living conditions, property ownership etc.) and there were injustices that led to excessive taxation.

Another breach of the principle of conformity was that the taxpayers who did not pay their tax debts were sent to the work camps and a part of the daily wage of 250 kurus was deducted for the collection of tax debt. In the letter, written on 13 November 1942, by the 
Ministry of National Defense to the Prime Ministry, the provision of the Article 12 of the Wealth Tax Law 'Application manner of the liability to work is determined with an instruction to be issued by the government' was reminded and it was specified that such instruction should be immediately issued to make the preparations for the affairs that would concern the Ministry of Defense. A similar letter was written by the Ministry of Finance to the Prime Ministry; however, the instruction draft was not issued despite all these correspondences (Koçak, 2004: 23). It is really difficult to say that the official authorities of the government adopted a corporate approach in the application of this sanction of work camp. As a conclusion, hundreds of Non-Muslim people were sent to Aşkale, which was a small town of the Eastern Anatolia, to work under severe winter conditions. However, no taxpayer from the groups $\mathrm{A}$ and $\mathrm{F}$ was sent to the work camps and tax amounts to be paid by the group $\mathrm{E}$ were reduced by the help of diplomats of their countries (Bali, 2011). Practice of work camp and discrimination arising from this practice were the most important factors that totally eliminated the principles of equality-generality in taxation.

In the annual report published in Monthly Journal of English Chamber of Commerce on February 27, 1943 in Istanbul, the Wealth Tax was defined as "a tax which is nothing but a heavy duty imposed on the capital" and it was stated that the tax gave damage to not only several traders but also to the stability of the whole market and the English exporters "had to preserve a prudent freedom of movement because of the tax (Koçak, 2004: 22). The Wealth Tax caused the formation of a table approached with caution at the international level and its negative influences on the economy were discussed.

The Wealth Tax did not regulate the income distribution or encourage investments; quite the contrary, it deteriorated the income distribution and prevented investments. Investments were negatively influenced by the fact that tax was imposed on the Non-Muslim service providers, but not on the Muslim group, and the tax imposed on the Non-Muslim businessmen was much higher than the tax imposed on the Muslim businessmen. The distribution of tax among the provinces was unequal in terms of the distribution of taxpayers and this was contrary to both equality and economy. 54 percent of the Wealth Tax was collected only from Istanbul. In Istanbul, number of the group $M$ taxpayers within the exceptional class was 460 and the tax imposed on these taxpayers was 17 million and 209 liras. This amount was nearly 6 times more in the group $\mathrm{N}$ than the group $\mathrm{M}$, number of the taxpayers was 2563 and the total tax imposed was 189 million 969 thousand and 980 liras. For the groups with scale, there were 924 taxpayers in the group M and 1259 in the group N. This number was 2589 in the group $\mathrm{M}$ and 24151 in the group $\mathrm{N}$ for the groups with revenue. There were 159 joint-stock companies, 22 contractors, 1937 real estate sellers and 788 districts. Together with 10991 service providers and $15413 \mathrm{~N}-\mathrm{M}$ partnerships, there were 61673 Wealth Tax payers in total (Ökte, 102-3). 
Table 1: Wealth Tax Payers in Istanbul

\begin{tabular}{|l|l|l|}
\hline & Taxpayers & Assesment of Income \\
\hline $\begin{array}{l}\text { The Group M (Exceptional } \\
\text { Class) }\end{array}$ & 460 & 17.209 .549 \\
\hline Muslims with Scale & 924 & 3.128 \\
\hline $\begin{array}{l}\text { The Group N(Exceptional } \\
\text { Class) }\end{array}$ & 2563 & 189.969 .980 \\
\hline Non-Muslims with scale & 1259 & 10.364 .466 \\
\hline
\end{tabular}

The inequality experienced during the application of the Wealth Tax did not end upon the revoke of this application. In 1943, three months after the publication of an interview series related to the tax applications by Cyrus L. Sulzberger, reporter of New York Times, and several days before the negotiation of Roosevelt and Churchill, leaders of the entente states in Cairo, İnönü, the Prime Minister, declared that the tax debtors in Aşkale would be released. A law that revoked the application of tax was approved by the assembly on March 1, 1944. In the letter signed by the Prime Minister and sent to the Ministries of Domestic Affairs, Finance and Public Works in relation to the tax debts on December 3, 1943, it was stated that a decision was taken to return the taxpayers, who could not pay their tax debts within the legal term and therefore were charged with the liability to work, to their families and provide them with the change to work in "work places" and pay their remaining debts (Koçak, 2004: 25). Wealth Tax was remitted as of March 1, but the pressures for the payment of tax debts went on. Such that, provisions of the Law on Collection of Assets were continued for a while to be applied to those who could not pay their debts.

Table 2: Wealth Tax Collection

\begin{tabular}{|l|l|l|}
\hline In Turkey(total) & Tax Payers & Taxe Obligation \\
\hline Taxpayers in workplaces & 2057 & 65.464 .236 \\
\hline Tax paid & 657 & 27.631 .313 \\
\hline Abatement & 1400 & 37.833 .223 \\
\hline In Istanbul & Tax Payers & Taxe Obligation \\
\hline Taxpayers in workplaces & 1869 & 59.005 .350 \\
\hline Tax paid & 640 & 25.908 .695 \\
\hline Abatement & 1229 & 33.096 .655 \\
\hline
\end{tabular}

Source: Kayra C., 2011, Savaş Türkiye Varlık Vergisi, Tarihçi Kitabevi, İstanbul, p.163. 


\subsection{The Role of Public in Wealth Tax: Sees And Seizures}

The most striking result of the Wealth Tax in terms of the process of the Turkification of economy, which is a practice of socialization, was the sales of or seizures on the properties of tax payers due to the tax. Decrease in inflation, which is the economic target of the tax, and control on emission of money by applying tax on excessive profits resulted in the handover of money and assets. Such that, the income acquired through Wealth Tax was used for non-productive purposes. Pledged properties were sold by the government to their new owners with considerably low prices. The new owners sold these properties with very high prices and acquired unlawful profits and thus made an important progress in capital transfer (Kobal, 2009: 23). In sales with Wealth Tax, the value of real estates was really high, the average sales price was 25.177 liras and it was way above 5.101 liras, which was the normal sales average (Aktar, 2010: 228). Such low-priced sales is seen as one of the kinds of seizure on the assets of a class in the extent that it has similar characteristics with the process called "flipping" in American real estate market. In the process starting with the sales of houses thought to be out-of-condition to low-income families with low prices under mortgage sales agreement, buyers cannot pay the installments and become obliged to resell the house (Harvey, 2004: 127). While real estates that the taxpayers dispose of for their tax debts are purchased by public enterprises or private persons, seizure on the taxpayers' assets with low prices is a part of the developmentalist state's action of participating in the system and regulating the capital accumulation (Harvey, 2004: 127) in crisis periods.

It was remarkable that 30 percent of the first buyers of the real properties sold due to the Wealth Tax were public enterprises and the process was declared to be nationalization (Aktar, 2010: 205). Among these public enterprises, there were SEEs such as Soil Products Office, Turkish Sugar Factories; national banks such as Sümerbank, Türkiye İş Bankası; national insurance companies such as Umum Sigorta Şirketi, Milli Reasürans and also foundations.

Seizures and sales were not limited to the taxpayers. Many families were influenced by such seizures and sales arising from the tax as the properties and cash assets of the families of those, who could not pay the Wealth Tax, were provided as tax guarantee (Aktar, 2010: 195). It was stipulated by the new Law that the non-paid debts would be paid by close relatives. (Aktar, 1999: 17)

Furthermore, there were many examples not complying with the Law on the Collection of Assets. According to Viktor Bneardette, a payer of Wealth Tax who experienced one of these examples:

The most unfair side was that, in the period of Wealth Tax, real estates were not sold in compliance with the provisions of the Law on the Collection of Assets. Pursuant to the law, a real estate may be sold 21 days after the declaration thereof. The declaration should be made in three gazettes, one of which is to be a gazette of the capital. However, most of these sales were made without waiting for 21 days, in violation of the law. Therefore, they were sold with much more lower prices than their actual values. Hence, my store with a value of 20,000 liras was sold for 1,300 liras and Alyanak Hanı, having been bought by my family for 125,000 liras, was sold for 65,000 liras" (online: www.rifatbal.com).

Besides the fact that the gazette declaration of the real estate sales arising from the tax was not made in compliance with the law, participants of the sales was also thoughtprovoking as it proved that violation of the principles of equality and universality continued in 
the sales. With all the damage to the justice of taxation, this caused a situation that "only the commission, seller and a number of persons with money in their pocket knew which real estate would be sold and where and with which price it would be sold", as stated by Ökte (Ökte, 1954: 163).

In the news and articles in the newspapers having the purpose of judging the aims of Wealth Tax payers, luxury properties put up for sale due to the tax were published. Another purpose of these publications was to reveal the wealth of the taxpayers in the eyes of the readers and prove that the tax amount was quite right:

Sales of seized goods and properties will take place tomorrow.

Auction of Değirmenci Kozmato, a jeweler and taxpayer, will be carried out on Tuesday.

It is estimated that an amount of jewelry had a value of 40 liras. Among the jewelry of the jeweler, there is a medal with a value of 200 liras, a brooch with a value of 100 liras, a ring with a value of 9 thousand liras, a woman's watch with a value of one thousand liras, a diamond brooch with a value of four thousand liras, a diamond ring with a value of 4 thousand liras and a beautiful green gemstone bracelet with a value of 35 liras ('Wealth Tax', Akşam, 27 January 1943, Akan. Akan, 2011: 619).

The sanction of labor camp had an important role in the performance of such quick sales and revival of seizures in relation to the Wealth Tax. There was a significant increase in the sales related to Wealth Tax between the dates 20 January-9 February 1943, when the first group went to Aşkale. The reason behind this increase was that the price of the real estate was used in clearing the tax debt (Aktar, 2010: 239).

When the Wealth Tax is in question, it would be better to look into the results of real estate sales arising from the tax in order to conclude that collection of the tax income has the covered purpose of ensuring handover of the assets. The targeted amount could not be collected and state expenses had an increase of 38 percent and national income had a decrease of 8 percent during the application of the Wealth Tax. The national income had an increase of 3.5 percent in the last period of the Wealth Tax; however, this was still far behind the targeted rate. Thus, upon the decrease in prices, a derivative market was created by the government, which played a significant role in capital transfer as the taxable assets purchased by the government (public enterprises and banks) with cheap prices were sold with high prices (Kobal, 2009: 23).

It was stipulated in the Article 14 of the Wealth Tax Law that "permit" certificates proving that the properties put on sale were not related to the Wealth Tax payer would be issued. For real properties, sold for paying the tax debt, a receipt showing that the tax was paid would be given to the seller, who is the taxpayer (Aktar, 1999: 13). The tax collected by the government was transferred to the third parties in return for real properties far below their market values.

16 percent of the sales in 1943 in Istanbul are directly related to the Wealth Tax and 2742 real estates were sold in this scope (Aktar, 1999: 13). Among the real properties sold, 18 office blocks were directly related to only wealth tax and 28 office blocks were sold by the Non-Muslims. The commercial buildings put on sale by the Non-Muslim, who paid 87 percent of the Wealth Tax, were the ones sold in order to pay the debts of Wealth Tax or debts 
of close relatives, family members debts of whom they were liable to pay. 36 office blocks sold by Muslim Turks reached the highest amount of sales, because the houses purchased in low prices by the public enterprises were sold with affordable prices. The fact that sales not directly related to the Wealth Tax were much higher among the office blocks in Istanbul proves the existence of derivative markets in capital transfer.

\subsection{ECONOMIC TRANSFORMATION GENERATED BY THE WEALTH TAX: SEIZURE FOR BAHTIYAR HAN}

A place is formed based on both individual needs and targets of the powerful. This is caused by the powerful's ideal of keeping its society under control. The political power may use the place to keep the society together; however, it may also take it away from the society's mind by removing the traces thereof (Asiliskender, 2006:204).

In terms of the Wealth Tax, sales of the commercial buildings meant that they were taken away from the society's mind. The intensive sales of and seizures for the commercial buildings, which had an important part in the determination of the tax and the payments, in Istanbul will provide important data for observing the formation of places by the political power. Şükrü Saraçoğlu stated that Wealth Tax base was applied in order to draw approximately 700 million liras from the extraordinary revenue of tradesmen, land and real estate owners and large farmers and the profits of tradesmen to be "determined by the commissions" constituted the biggest share and also emphasized that the second base consisted of commercial buildings, bathhouses and apartments (Akar, 2009: 61).

It was targeted that Istanbul Financial Directorate would collect a tax of 300 million liras in Istanbul; however, there were increases in the tax amount despite the fact that the decision of the commission in Istanbul on tax rate was approved by Ankara. It is asserted that behind these increases there were Şükrü Saraçoğlu's demands to impose a tax amount above the general average, especially to Jews.

When the real estates in Galata, which were seized upon the Wealth Tax, are examined, it is seen that the commercial buildings including workplaces of many tradesmen and exporters are prominent. Those whose real estates were seized could not avoid from being send to work camps in order to pay their debts because of the seizure on their properties far below their real values:

Taxpayers will earn 250 kurus per day, 60 kurus will be allocated for income tax and extraordinary taxes, half of the remaining 190 kurus will be deducted from the Wealth Tax debt and the other half will be spent for food and accommodation ('Varlık Vergisi: Çadırlar, Kazmalar ve Yataklar Doğu İllerine Gönderildi', İkdam, 9 January 1943, Akan, 2011: 617).

In a study about the influence of the Wealth Tax on investments of the non-Muslim and the foreign, largely focusing on the textile industry, it is stated that there was the unease arising from the Wealth Tax behind the non-Muslim tradesmen's unwillingness to shift from trading to manufacturing (Clark, 1985: 36). It is possible to state that information provided by the taxpayers, whose factories in Galata were seized, support this study. For Rafael Elvuşvili, Savaş Melikyan, Sitati Panayati and their partners, the seized factories and for Mihran Ohanyan, the savings in shoemaking sector were wasted in Galata (Ergüder, 2011: 391-2).

Apart from the commercial buildings of families engaged in trading, importing and brokering, there were also self-employed persons like Şekip Adut and Gad Franko. Şekip Adut could not pay the tax imposed in the amount 375,000 liras and his real properties only in 
Galata together with the workplaces in different parts of Istanbul were seized in return for 12,500 TL (Çetinoğlu, 2009: 471). The attitude towards Gad Franko, who objected to the Wealth Tax and set the cat among the pigeons with his warnings not to pay this tax, demonstrates the role of public enterprises in the creation of bourgeoisie by the government. Response of Şükrü Saraçoğlu to the tax debt of Gad Franko is very interesting in this respect:

The government may ask for everything one has, even his life. But how could it as for something that he does not have? (Bali, 1997: 52). An important name in the areas of law and trade, Gad Franko, was a symbol as a leading person with his intellectuality Jewish community (Bali, 2010: 121). Many articles of Franko were published in El Commercial, a local publication established by Hizkia Franko, brother of Gad Franko, in İzmir in 1905 and, besides his writings in this period, he was recognized a good writer with his articles in Turkish in İzmir and İstanbul. Having completed law education in Paris, he developed himself in the field of law in Istanbul. (Bunis, 2012: 66).

There are various answers to the question why such a person was overwhelmed by a really heavy burden related to the Wealth Tax and sent to the work camp. It is not exactly known whether it is caused by his opposition to the Wealth Tax or his being a well-known and rich advocate. In the first days of the application of Wealth Tax, Faik Ökte, head of the Financial Directorate, got together with Muzaffer Akalın, the Deputy Governor of Istanbul, requested the determination of those who stood out against the tax, and Gad Franko, Şekip Adut and Faracci were placed to the top of the list prepared. There is no doubt that the increasing objections of Gad Franko, who issued the first private law journal of the Republic Period and wrote an annotation of Turkish Civil Code, played a role in the tax amount he had to pay (Bali, 2005a: 160). His opposition and legal formation gave both power and vulnerability to Franko:

Franko was a lawyer with an experience of fifty years... He was not very wealthy, but he was the demanded man of wealthy communities with his manner. Although he wanted to keep himself behind, the events thrust him to the forefront and he could not prevent this attention-grabbing thrust. And eventually, these events cost him a tax of 350 thousand liras. Even Franko did not know what to do (Karakoyunlu, 1990: 131).

It is another assumption that his luxury lifestyle within his close circle of friends had an influence on this high amount of tax, even not as much as his objections to the tax (Bali, 2010: 131). An indication of this lifestyle and the sales of Bahtiyar Han, where his law office was located, deserves to be examined as a response to Franko's opposition to the Wealth Tax and an example of the handover of capital by the government (Bali, 2010: 131).

Gad Franko's financial situation overwhelmed by the tax of 420 thousand liras imposed on his son played a role in the seizure on Bahtiyar Han, located on the Bankalar Caddesi in Galata and belonging to Gad Franko, on whom 377 thousand liras tax was imposed, and its sales to the Soil Products Office (Bali, 2005b: 350). Even though Franko paid 100 thousand liras of this tax in cash and stated that he would pay the remaining part, all his property was confiscated in 15 days. There was also Bahtiyar Han among the properties confiscated before the tax payment term expired. The building with value of 400 thousand liras disposed and hypothecated in return for 100 thousand Liras. Also, an auction was held in Franko's house (Bali, 2010: 137).

Franko's answer to the receiver charged in the seizure of Bahtiyar Han was noted by the receiver as follows: "You took all my property. Take everything I have, including my life. Write this to Ankara excactly like this" (Karakoyunlu, 1990: 132). Saraçoğlu's response to this reaction reflects the spirit of the period: "Franko is an intellectual man. He is an important 
lawyer. He is my teacher. I kissed his hands many time. But, he insists on not paying...He should work and pay now... (Karakoyunlu, 1990: 132).

Bahtiyar Han, belonging to Gad Franko, was constructed in 1903 and owned by Camondo family, which was an important family in the world of finance, between the years 1913 and 1944. In this commercial building, there were enterprises like Camondo Company (1913), M. Franko and Associates, AEG Türk Anonim Elektrik Şirket'i Umumiyesi, Barsak factory owned by Chiakamo Behar, Bozkurt Insurance Company, containing the members of Franko family. In AEG Türk A.Ş., Marsel Franko, brother of Gad Franko, was partners with Danyel Burla. Bahtiyar Han, having important architectural characteristics, was one of 15 new commercial buildings added to the street during the rush of construction which continued until the First World War and one of the earliest examples of the reflection of modernity on architecture (Eldem, 2000: 242).

Soil Products Office, having taken over the building, was a state economic enterprise and founded to be engaged in wheat affairs in 1938. Soil Products Office was founded with the purpose of regulating the wheat prices in order to prevent price increase of wheat, which is one of the agricultural products of shortage during the Second World War, both by producers and consumers. The Office, which was charged firstly with import and in the following years with export of wheat, had the authority to establish factories in the places deemed necessary. Authorities of the Office was extended with the duty of purchasing vegetable and animal oils, mean and fish, alfalfa seed and legumes, particularly barley and oat on 27 October 1939, rye on 28 April 1940, corn on 25 April 1941 and rice on 13 August 1941. Soil Products Office established warehouses in various kinds and tonnages, considering the ports and intensive production sites, and the total warehouse capacity reached 4 million tons.

The government initiated direct and indirect price support program in wheat and tobacco purchase in 1932 for the agriculture prices that suddenly decreased in the crisis of 1929. Firstly Ziraat Bankasi and then the Soil Products Office, which was an independent enterprise, started to purchase wheat from the producing villagers. Wheat purchase by the government prevented the decrease in wheat prices, but could not turn the tables on the clear deterioration in domestic trade suffered by the producers. The government founded the Soil Products Office which would regulate the prices of agricultural products in order to retain the agricultural surplus and accelerate the industrialization attempt in cities (Owen and Pamuk: 1998, 36). It is important that the Office, which was a regulatory institution for the important outputs of the agriculture economy during the Second World War, took over a commercial building containing center offices of factories in Galata, which was a significant port of the Ottoman urban economy formed with the trade of agricultural products and then became a financial center. This indicates that formation of trade and the developing manufacture industry was led by SEEs under the supervision of the government.

Just like Gad Franko, the previous owner of Bahtiyar Han, the new owner Soil Products Office is also a liable to pay Wealth Tax. Wealth Tax amount imposed on the Soil Products Office is TL 2,548,000. Many public enterprises took the first ranks with a tax assessment of more than TL 15,000 among the taxes collected from Turkish and Muslim people. In addition to the Soil Products Office, public enterprises centers of which were located in Ankara like Ziraat Bankas1, Sümerbank, Emlak ve Eytam Bankas1, the Central Bank, Ereğli Kömürleri, Türkiye İş Bankası, Istanbul Security Fund were accrued a considerable amount of tax (Baş, 2006: 220). In this respect, the government's collecting tax from public enterprises creates a view of balance in terms of capital transfer. Such that, the excessive profits acquired from real estate seizures turned into public revenue and taxes 
imposed on public enterprises remained in really low rates. Seizures prevented the payment of the taxpayers' debts. Gad Franko did not pay the Wealth Tax and was relegated to Aşkale. Franko and his friends, having taken place in the group of 47 companies that went to the work camp, started their Aşkale journey from Kadıköy:

Properties of 47 companies in the business centers and workshops were seized. 18 taxpayers were sent to Kadlköy to be brought to the work camp. Among the names sent to the work camp in Aşkale, there were Çuhaciyan (cotton trader), Yermina Varon (textile trader), Samoel Yarman (owner of iron factory), Garbis Baykar (trader), SSekip Adut (advocate), Gad Franko (advocate)... Tax debt of these taxpayers was more than TL 200,000. They would stay in Kadlköy and, the next day or the day after, they would be sent to Aşkale ('Vergi Kaçıran 47 Şirkete El Konuldu', Akşam, 22 January 1943, Akan, 2011: 618).

During the days he passed in the work camp, Franko believed that the government would correct this mistake. However, the opinion having spread among the taxpayers was different from Gad Franko's approach.

"The government has broken tax ethics of the taxpayers. This is the biggest failure of the Republic"(Karakoyunlu, 1990: 153).

When the first excitement of the groups having returned from the work camp was settled, the fear of the changed level of their life in Istanbul arouse and the real collapse started for these "groups of people whose properties were taken away". Franko read the full text of the Law that revoked the Wealth Tax and thought with astonishment how a violence turned into such an easy character in such a short time. Mr. İbrahim, his colleague, thought the same way: "The unpaid taxes were written off; what happened had all happened to those who paid" (Karakoyunlu, 1990: 153).

Franko family was influenced by this relegation. Marcel Franko, brother of Gad Franko, who was the chairman of Turkish Jewish Community in 1930s moved to America upon the tax application and became the chairman of the Committee of Eastern Studies (Bali, 2005b: 350). In 1923, approximately 80,000 Sephardi Jews living in the Republic of Turkey suffered the cultural and economic Turkification applied between the years 1923 - 1945, with several anti-semitic events like Thrace Pogroms ${ }^{2}$ in 1934 and application of Wealth Tax to all minorities in 1942 (Bihar, 2011: 49). Among these applications, Wealth Tax should be seen as an important milestone in terms of the Turkification process of the economy.

\section{CONCLUSIONS}

When evaluated in terms of public finance, this extraordinary tax having led to the violation of taxation principles had economic targets like decreasing the money supply and inflation in the market during the financial turnaround in the years of the Second World War and limiting the unfair war incomes having increased during the war; however, the main target was to create a market that was convenient for Turkish bourgeoisie. Application of the provisions of the Law on Collection of Assets for a while was the most obvious indicator of this situation. It was inevitable to experience a period in which the seized properties of taxpayers, who could not pay the tax debts, were sold in really low prices to their new owners by the government and thus new unjust profits were acquired. New owners of the seized real estates acquired unearned profit by selling them with high prices and capital transfer to the national bourgeoisie was realized. 
Properties seized due to the Wealth Tax or sold with prices lower than their real values led to the formation of a derivative market by the government. The largest buyers in this market were public institutions and banks. The process experienced through the seizure on Bahtiyar Han and its sales to the Soil Products Office because of the inability of Gad Franko, a lawyer and an intellectual, to pay his debts summarizes the active role of the government in the social practice of the Turkification of economy by the agency of public enterprises. 


\section{REFERENCES}

AHMAD, F., 2008, From Empire to Republic, Volume.1, Bilgi Üniversitesi Yayınları, İstanbul, 9786053990567

AKAN, A.,2011, A Critical Analysis of the Turkish Press Discourse against Non-Muslims: A Case Analysis of the Newspaper Coverage of the 1942 Wealth Tax, Middle Eastern Studies, 47(4), 605-621.

AKAR, R., 2009, Aşkale Yolcuları: Varlık Vergisi ve Çalışma Kampları, Doğan Kitap, İstanbul, 9786051113944

AKTAR, A., 1999, Varlık Vergisi Işığında Gayrımenkul Satışları: İstanbul Tapu Kayıtlarının Analizi (26 Aralık 1942-30 Haziran 1943), Toplumsal Tarih Dergisi, 69(3), 10-22.

AKTAR, A., 2010, Varlık Vergisi ve Türkleştirme Politikaları, İletişim Yayınları, İstanbul, 9754707790.

AKTAR, A. ,2013, “Tax To Me To The End Of My Life!: Anatomy of An Anti-Mİnority Tax Legislation (1942-3)", in State, Nationalisms in The Ottoman Empire, Greece and Turkey, ed. Benjamin C. Fortna, Stefanos Katsinas, vd., USA: Routledge P., 188221.

AKTÜRK, Ş.,2007, Continuity and Change in the Regimes of Ethnicity in Austria, Germany, the USSR/Russia, and Turkey: Varieties of Ethnic Regimes and Hypotheses for Change, Nationalities Papers: The Journal of Nationalism and Ethnicity, 35(1), 23-49.

ASILISKENDER, B., 2006, Kayseri Eski Kent Merkezi'nde Cumhuriyet'in İlanından Günümüze Mekân ve Kimlik Deneyimi, Erciyes Üniversitesi Fen Bilimleri Enstitüsü Dergisi 22(1-2) 203-212.

BALI, R.,1997, Varlık Vergisi Üzerine Tartışmalar, Tarih ve Toplum Dergisi, 165(4), 47-60.

BALI, R., 2001, "Toplumsal Bellek ve Varlık Vergisi”, der: Esra Özyürek, in Hatırladıklarıyla ve Unuttuklarıyla Türkiye'nin Toplumsal Hafızası, 87-126.

BALI, R., 2005a, Cumhuriyet Yıllarında Türkiye Yahudileri: Bir Türkleştirme Serüveni, İletişim Yayınları, İstanbul, 9754707634.

BALI, R, 2005b, The "Varllk Vergisi” Affair: A Study on Its Legacy, Selected Documents, The Issis Press, İstanbul, 9786054326556.

BALI, R., 2010, Devletin Yahudileri ve Öteki Yahudi, İletişim Yayınları, İstanbul, 9789750502040.

BALI, R. 2011, The Slow Disapperance of Turkey's Jewish Community(online), [erişim tarihi: 16 Aralık 2013], http://jcpa.org/researcher/rifat-bali>

BALI, R., 2012, 1952 Yılı Hizmet Gazetesi'nin Varlık Vergisi İle İlgili Yayını(online), [erişim tarihi: $\quad 5 \quad$ Ocak http://www.rifatbali.com/images/stories/dokumans/hizmet_gazetesi.pdf>

BIHAR, R., 2011, İstanbul Türk Yahudi Cemaati Tiyatrosu: Geçmişten Günümüze Gelişimi (1860-2008), Mediterraneo, 4(3),47-69.

BUĞRA, A., 1996, Devlet ve Isşadamları, İletişim, İstanbul.

BUNIS, D. M., 2012, The Anti-Castilianist Credo of Judezmo Journalist Hizkia M. Franco (1875-1953), e-Humanista, 20(1),63-97. 
CLARK, E.,1985, Türk Varlık Vergisi’ne Yeniden Bakış, Yapıt Dergisi, 8(4),29-43.

ÇALIŞ, Ş., 1997, Pan-Turkism and Europeanism: A note on Turkey's 'pro-German neutrality' during the Second World War, Central Asian Survey, 16(1), 103-114.

ÇETINOĞLU, S., 2009, Varlık Vergisi 1942-1944, Belge Yayınları, İstanbul.

DINLER, D., 2003, Türkiye'de Güçlü Devlet Geleneği Tezinin Eleştirisi, Praksis Dergisi, say1:9(1), s.17-55.

ELDEM, E., 2000, Bankalar Caddesi: Osmanlı'dan Günümüze Voyvoda Caddesi, Osmanlı Bankası Araştırmaları Yayınları, İstanbul,

ERGÜDER, B., 2011, Galata Hanları: Paranın Serüveni (1868-1945), SAV Yayınları, İstanbul,9786056157967.

HARVEY, D., 2004, Yeni Emperyalizm, Everest Yayınları, İstanbul,978752891890.

İNSEL, A., 2001, Türkiye Toplumunun Bunalımı, Birikim, İstanbul.

JESSOP, B., 2008, State Power, Polity Press, London.

KARAKOYUNLU, Y.,1990, Salkım Hanımın Taneleri, Doğan Kitap, İstanbul.

KARABACAK, Y., 2005, Kapitalist Sistemlerde Devletin Görevleri ve Vergileme Gücünün Sınırları: Türkiye Örneği, İstanbul Üniversitesi İktisat Fakültesi Maliye Araştırma Merkezi Konferansları, 48(3), 108-136.

KAYRA, C., 2011, Savaş Türkiye Varlık Vergisi, Tarihçi Kitabevi, İstanbul, 9786056153341.

KEYDER, Ç., 1982, Türkiye'de Devlet ve Sinıflar,Yurt, Ankara,

KOBAL, E., 2009, Role Of The Wealth Tax Law in The Turkish National Bourgeoisie Formation Process, Eng. D. Thesis, Ankara: TED Ankara College Foundation High School.

KOÇAK, C., 2004, Varlık Vergisi Üzerine Birkaç Belge: Varlık Vergisi'ne Tepkiler, Toplumsal Tarih Dergisi, 122(2), 22-25.

LEFEBVRE, H. (2003), "Space and State", der: Brenner, N., in State/Space A Reader, Blackwell Publishing, London, 84-101,9780631230342.

MANN, M., 2003, “ The Autonomous Power of The State:Its Orgins, Mechanisms and Results", der: Brenner, N., in State/Space A Reader Blackwell Publishing, London, 53-65, 9780631230342.

OWEN, R. ve PAMUK, Ş., 2008, 20. Yüzyllda Ortadoğu Ekonomileri Tarihi, çev: Ayşe Edirne, Sabancı Üniversitesi Yayınları, İstanbul.

ÖKTE, F.,1954, Varlık Vergisi Faciası, Nebioğlu Kitabevi, İstanbul.

ŞIMŞEK, H., 2009, “Çanakkale Bağlamında 1934 Trakya Yahudi Olayları”, CTAD Yıl 5, 9 (3), 137-150.

YALMAN, G., 2002, Tarihsel Perspektiften Türkiye'de Devlet ve Burjuvazi”, Praksis Dergisi, 5(1), 7-23. 


\section{Notes}

\footnotetext{
${ }^{1}$ The tax imposed on Gad Franko was stated as 377 thousand liras in all scientific studies examined in relation to the Wealth Tax and referred to in the article and the approximate amount of the tax to be paid by Gad Franko, one of the characters in "Salkım Hanım'ın Taneleri" written by Yılmaz Karakoyunlu, was given as 350 thousand TL.

${ }^{2}$ Gad Franko played an important role in 1934 Thrace pogroms. Upon the spread of events to the other provinces of Thrace, Gad Franko went to Ankara together with Mişon Ventura and got an appointment from Atatürk and requested help (Şimşek, 2009: 145).
} 